\title{
Human Eosinophil-Lymphocyte Interactions
}

\author{
Peter F Weller ${ }^{+}$, Kaiser Lim
}

\author{
Department of Medicine, Beth Israel Deaconess Medical Center, DA-617 Harvard Medical School, 330 \\ Brookline Ave., Boston, MA 02215, USA
}

While the eosinophil's effector functions clearly can contribute to the pathogenesis of allergic diseases, the evolutionary benefit to having eosinophils as a distinct class of leukocytes is not clear, especially if one must reconsider the nominally beneficial role of eosinophils in parasite host defense. Eosinophils are equipped to respond to lymphocytes and their cytokines (and not solely the eosinophil growth factor cytokines), but the functional consequences of such eosinophil responses need to be defined. Conversely, eosinophils, as antigen-presenting cells (APCs) or sources of lymphocyte-active cytokines, may stimulate and effect lymphocyte functioning. Eosinophils share with $C D 4^{+}$lymphocytes expression of a number of receptors, including CD4 and IL-2R, and specific $\alpha 4$ integrins that may help in their common recruitment and activation. Further, elucidation of the interactions between lymphocytes and eosinophils will contribute to a broader understanding of the functioning of eosinophils in "normal" ongoing immune responses and in allergic disorders.

Key words: human eosinophil - lymphocite interactions - allergic disorders

Knowledge of the functions and functioning of human eosinophils as participants in immune responses remains incomplete. Normally in health, the eosinophil is principally localized in submucosal tissue sites, including the respiratory tract; but there is virtually no knowledge of how eosinophils become localized in these submucosal sites or what roles eosinophils play in normal, ongoing immune responses in these sites. Even in diseases characterized by eosinophilia, helminthic infections and allergic diseases, the functions of eosinophils are incompletely understood.

Infections with helminthic parasites elicit eosinophilia, mediated by IL-5. Based on in vitro studies demonstrating that eosinophils function as helminthotoxic effector cells (Butterworth 1984), it has been hypothesized that a major "beneficial" function of eosinophils is to participate in host defense against helminthic parasites. This putatively beneficial role is contrasted with some of the deleterious effects of eosinophils identified for allergic diseases. Recent studies with anti-IL-5 antibody-treated, helminth-infected mice, however, have questioned this role. In mice infected with helminthic parasites, neutralizing anti-IL-5 antibody has abrogated infection-induced blood, mar-

Supported in part by grants (AI20241, AI22571) from the National Institutes of Health and the MWV Leukocyte Research Fund.

${ }^{+}$Corresponding author. Fax:+1-617-277-6061. E-mail: pweller@bidmc.harvard.edu

Received 3 September 1997

Accepted 30 September 1997 row and tissue eosinophilia. In these anti-IL-5 (or anti-IL-4)-treated, eosinophil-deficient mice, intensities of infections (both primary and secondary) have not been greater than in eosinophilic mice (Sher et al. 1990, Herndon \& Kayes 1992). Analogous findings have been noted with parasitic infections in IL-5 knockout mice (Foster et al. 1996) (PS Foster, unpublished). These findings argue against a major role for eosinophils as helminthotoxic effector cells. While it is possible that other host defense mechanisms against helminths are sufficiently redundant that eosinophil ablation is not deleterious, these findings with depletion of eosinophils raise the possibility that eosinophils do not have a predominant helminthotoxic effector function in host defense (Urban et al. 1992). Thus, the nominally beneficial function of eosinophils in parasite host defense remains to be validated.

In allergic diseases, eosinophils are clearly participants and have effector roles in promoting the pathogenesis of these diseases. Eosinophils release lipid mediators, including leukotriene $\mathrm{C}_{4}$, platelet activating factor and lipoxins (reviewed in Weller 1993), and contain four distinct granule cationic proteins, major basic protein, eosinophil peroxidase, eosinophil cationic protein and eosinophil derived neurotoxin, which may cause dysfunction and destruction of other cells (reviewed in Gleich et al. 1992). These effector responses can be enhanced by exposures to specific eosinophil-active cytokines, including the eosinophil growth factor cytokines, GM-CSF, IL-3 and IL-5, which can be derived from $\mathrm{T}$ cells, potentially of the Th2-like phenotype. It has long been recognized that eosi- 
nophils from eosinophilic donors exhibit metabolic, morphologic, and functional changes indicative that they have been "activated" in vivo. Ongoing studies continue to provide evidence for this cytokine "activation" of eosinophils. While the eosinophil-active growth factor cytokines contribute to the process of eosinophil "activation", these cytokines alone do not elicit all measures of eosinophil activation, such as enhanced expression of FceRI (Gounni et al. 1994a) or CD40 (Ohkawara et al. 1996) found on eosinophils from allergic subjects. Other cytokines or tissue or extracellular matrix derived activating stimuli are likely to be involved as well in augmenting specific functional capabilities of eosinophils (Sedgwick et al. 1995).

Allergen-induced recruitment of eosinophils into lung tissues is correlated with roles of $\mathrm{CD} 4^{+}$ $\mathrm{T}$ cells, presumably Th 2 cells, and cytokines released by such T cells (Iwamoto et al. 1993, Van Oosterhout et al. 1993, Foster et al. 1996). In humans, IL-5 and to a lesser extent GM-CSF were the predominant eosinophil survival-promoting cytokines in antigen-induced pulmonary late-phase reactions (Ohnishi et al. 1993). The accumulation of eosinophils in tissues, as in chronic asthma or following acute antigen challenges in the lungs, correlates with measures of local T cell activation (Wardlaw \& Kay 1992). For instance, increases in activated $\mathrm{T}$ lymphocytes, eosinophils, and cytokine mRNA expression for IL-5 and GM-CSF have been documented in bronchial biopsies after allergen inhalation challenge in atopic asthmatics (Bentley et al. 1993). Thus, there has been an increasing recognition that eosinophil accumulation and enhanced effector functions at tissue sites of allergic reactions may be intimately related to lymphocyte activation, especially by nominally Th2like lymphocytes elaborating cytokines, including IL-5 and GM-CSF, that prolong the viability and enhance the effector responses of mature eosinophils.

While there has been an increasing recognition of the roles of lymphocytes in both the pathogenesis of allergic reactions and the regulation of eosinophil involvement in such reactions, our central hypothesis, that there exist collaborative interactions between lymphocytes and eosinophils in respiratory tract tissue environments, is based on a number of additional observations and considerations, as reviewed below. If eosinophils function to help regulate lymphocyte responses to aeroallergens encountered in the respiratory tract, such functions may be both "beneficial" in normal mucosal immune responses and deleterious in contributing to sustaining or propagating allergic reactions within the airways.

\section{EOSINOPHILS AS AIRWAYS ANTIGEN-PRESENTING CELLS FOR LYMPHOCYTES}

In hypothesizing roles for eosinophils as APCs, capable of eliciting specific lymphocyte responses, a series of older observations on eosinophils can be revisited and reinterpreted in light of our current understanding of APCs.

Studies in the 1960's documented a remarkable capacity of eosinophils to internalize administered antigen and to rapidly traffic to regional lymph nodes. Primary injection of varied antigens $\left({ }^{3} \mathrm{H}-\right.$ or fluorescently labeled) into the foot pads of mice or guinea pigs was followed by antigen uptake within eosinophils. Within one hr of antigen injection, eosinophils containing the labeled antigens localized within regional lymph nodes (Litt 1964b, Roberts 1966). Uptake of antigen preferentially into eosinophils was even greater when antibody to the antigen was present (Litt 1964a). Moreover, repeated administration of antigen lead to even greater localization of antigen-containing eosinophils in draining lymph nodes (Litt 1963). Specific histologic stains to detect eosinophils in tissues facilitated this recognition (Litt 1964a, b, Roberts 1966). While these findings by themselves do not establish that eosinophils were serving as APCs, these experiments do document roles for eosinophils in the very early uptake of antigen, do indicate a role for antibody-facilitated uptake of antigen by eosinophils, as antibody-facilitated uptake of antigen is now recognized to enhance APC function, and do suggest that eosinophils exhibit specific integrin-based or other mechanisms for preferential localization within lymph nodes.

\section{EOSINOPHILS AS POTENTIAL ANTIGEN-PRESENT- ING CELLS}

If human eosinophils are to serve as effective APCs in vivo, several conditions must be satisfied. Further, given the diversity of cells that may function as professional and non-professional APCs, consideration must be given to what specific capabilities eosinophils might have as distinct APCs. - For eosinophils to function as APCs, they must express Class II MHC proteins. Blood eosinophils, from most normal and eosinophilic donors, lack expression of Class II MHC proteins, even if these circulating eosinophils otherwise exhibit evidence of phenotypic in vivo activation (Lucey et al. 1989b). However, when mature, blood-derived human eosinophils are cultured in vitro with specific cytokines, including IL-3, GM-CSF, and IFN- $\gamma$, these eosinophils are uniformly induced to synthesize and express HLA-DR (Lucey et al. 1989b, Weller et al. 1993, Guida et al. 1994). Thus, mature eosinophils have the capacity to express HLA-DR. 
- Is there evidence that eosinophils in vivo express HLA-DR? Notably, a number of observations document that airway eosinophils are positive for HLA-DR expression. Eosinophils in the sputum of asthmatics have been shown to express HLADR (Hansel et al. 1991). Airway, but not blood, eosinophils in chronic eosinophilic pneumonia also have been demonstrated to express HLA-DR (Beninati et al. 1993, Okubo et al. 1995, Sakamoto et al. 1995b). In patients with asthma, even blood eosinophils have been found to express greater HLA-DR than eosinophils from normals (Sakamoto et al. 1995a). Moreover, comparisons of blood and bronchoalveolar lavage eosinophils obtained $48 \mathrm{hr}$ after segmental antigen (Sedgwick et al. 1992) or 4-6 hr after inhalational (Mengelers et al. 1994) challenges in allergic subjects have demonstrated that HLA-DR was expressed on airway eosinophils. Thus, the recruitment and activation of eosinophils into the airways elicited by allergen challenge leads to the induction of HLADR expression on the recruited airways eosinophils, which was not found on the otherwise phenotypically activated blood eosinophils (Sedgwick et al. 1992, Mengelers et al. 1994). Levels of Class II MHC protein expression need be only low (210$340 /$ cell) for a cell to function as an APC (Harding \& Unanue 1990). Levels of HLA-DR fully sufficient for APC function are present on eosinophils from the airways as recovered in the sputum or airway lavages from allergic subjects.

- If eosinophils are to function as APCs, eosinophils must be able to internalize protein, catabolize it and display the relevant peptides with Class II MHC molecules. We have shown that eosinophils do function as HLA-DR dependent, MHCrestricted antigen-presenting cells in stimulating allogeneic T cell responses (Weller et al. 1993). Comparable findings have been made with human T cell lines as responders (Hansel et al. 1992, WyssCoray et al. 1993) and with murine eosinophils (Del Pozo et al. 1992, Tamura et al. 1996).

- While presentation of antigen with MHC is necessary, full APC function (i.e. "professional" APC) requires the presentation of co-stimulatory signals by the APC. Accessory co-stimulatory molecules pair with specific receptors on the T cell. The recognized molecular pairs include B7-1 (CD80) or B7-2 (CD86) with CD28 or CTLA-4, ICAM-1 (CD54) or ICAM-2 with LFA-1 (CD11a/CD18), LFA-3 (CD58) with CD2, and Class I and II MHC molecules with CD8 and CD4, respectively. In addition, engagement of CD40 on APCs can provide co-stimulation (Cella et al. 1996, Peng et al. 1996). We have demonstrated that eosinophils from allergic subjects express CD40 (Lim et al. 1996b, Ohkawara et al. 1996) and that eosinophil CD40 provides co-stimulatory signals to CD3-ac- tivated T lymphocytes (Lim et al. 1996b). Other co-stimulatory molecules expressed by eosinophils include ICAM-1 (CD54), which like HLA-DR is absent from circulating eosinophils, but can be found on airway eosinophils and can be induced to be expressed in vitro with specific cytokines (Czech et al. 1993, Hansel et al. 1992). Other eosinophil-derived chemokines or cytokines that can have additional lymphocyte stimulatory activities are noted below. Thus, eosinophils have the capacity to express Class II MHC, to present antigen and to express relevant co-stimulatory molecules if such are induced in vivo or in vitro.

\section{OTHER LYMPHOCYTE-EOSINOPHIL INTERACTIVE MECHANISMS}

Eosinophils as sources of lymphocyte-active cytokines - Our studies and those of others have documented that human eosinophils can synthesize cytokines that include TGF- $\alpha$ (Wong et al. 1990, Elovic et al. 1994), TGF- $\beta 1$ (Wong et al. 1991, Ohno et al. 1992, Elovic et al. 1994), TNF$\alpha$ (Beil et al. 1993, Costa et al. 1993), MIP- $1 \alpha$ (Costa et al. 1993), IL-5 (Broide et al. 1992; Desreumaux et al. 1992), GM-CSF (Kita et al. 1991, Moqbel et al. 1991, Ohno et al. 1991, Broide et al. 1992), IL-3 (Kita et al. 1991), IL-1 $\alpha$ (Weller et al. 1993), IL-6 (Hamid et al. 1992, Melani et al. 1993), IL-8 (Braun et al. 1993), IL-2 (Bosse et al. 1996, Levi-Schaffer et al. 1996), IL-10 (Lamkhioued et al. 1995), IL-4 (Moqbel et al. 1995, Nonaka et al. 1995, Sabin et al. 1996), RANTES (Lim et al. 1995, 1996a; Ying et al. 1996) and IL16 (Lim et al. 1995, 1996a). We have shown that human eosinophils elaborate lymphocyte chemoattractant activity that is largely mediated by RANTES and IL-16 (Lim et al. 1995). Thus, human eosinophils are a source of a cytokine (IL16) and a chemokine (RANTES) specifically effecting the functioning of $\mathrm{CD}^{+}$lymphocytes (Cruikshank et al. 1994, 1996) and memory T cells (Schall et al. 1990), respectively.

In addition, other eosinophil-derived cytokines, including IL-2 (Minami et al. 1993), IL-4 (Aiello et al. 1990, Sabin et al. 1996), MIP-1 $\alpha$ (Taub et al. 1993), IL-1 $\alpha$ (Ruppert \& Peters 1991), IL-6 (Ruppert \& Peters 1991) and TGF- $\beta 1$ (Ahuja et al. 1993, Lee \& Rich 1993), have effects on lymphocytes. Several beta chemokines, that can be elaborated by eosinophils, including MIP- $1 \alpha$ and RANTES, augment APC function and T cell responses and hence are co-stimulatory (Taub et al. 1996). Thus, in addition to eosinophil-lymphocyte cell-cell cognate interactions that may be active in APC functioning of eosinophils, eosinophils can be sources of chemokines and cytokines active on lymphocytes. 
Eosinophil integrins - The expression of specific integrins by eosinophils not only may contribute to their preferential recruitment into sites of allergic diseases but also may help regulate their activation within extravascular tissues (Resnick \& Weller 1993) and their cell-cell interactions (Muñoz et al. 1996). We and others have shown that eosinophils, and not neutrophils, express the $\alpha 4 \beta 1$ integrin VLA-4 (Bochner et al. 1991, Dobrina et al. 1991, Weller et al. 1991). VLA-4 binds to vascular cell adhesion molecule-1 (VCAM) and to domains within tissue fibronectin (Elices et al. 1990). VLA-4, which is expressed in common on eosinophils as well as lymphocytes and monocytes, but not neutrophils, can mediate binding to VCAM, whose expression is inducible on endothelial cells and can be demonstrated to be expressed in asthmatic bronchial vessels (Ohkawara et al. 1995). By this means, preferential recruitment or activation of eosinophils and mononuclear leukocytes might be expected.

Additionally, we have shown that eosinophils express another $\alpha 4$ integrin, $\alpha 4 \beta 7$ (Erle et al. 1994, Wan et al. 1995). The expression of $\alpha 4 \beta 7$ on eosinophils is intriguing given the role this integrin plays in binding to the mucosal vascular addressin MAdCAM-1 (Berlin et al. 1993) and the enhanced expression of $\alpha 4 \beta 7$ on a subsets of mucosal trophic $\mathrm{CD}^{+}$memory $\mathrm{T}$ lymphocytes (Schweighoffer et al. 1993, Rott et al. 1996). MAdCAM-1 is known to be expressed on high endothelial venules of Peyer's patches and mesenteric lymph nodes and sinus-lining cells in the spleen (Kraal et al. 1995). The common expression by eosinophils and some lymphocyte populations of $\alpha 4 \beta 7$ may contribute to their co-localization within lymphoid tissues. Moreover, the $\alpha 4$ integrins have been shown to be involved in cognate cell-cell interactions (Muñoz et al. 1996) including those specifically between human lymphocytes and eosinophils (Mengelers et al. 1995).

Studies with blocking mAbs to the $\alpha 4$ component of both $\alpha 4 \beta 1$ and $\alpha 4 \beta 7$ have demonstrated that such blockade can prevent eosinophil influx into cutaneous or pulmonary sites of elicited allergic reactions (Weg et al. 1993, Pretolani et al. 1994). Moreover, blockade of $\alpha 4$ integrins can have beneficial effects on allergic reactions even without inhibiting eosinophil influx. In our collaborative studies, the administration of a blocking anti- $\alpha 4$ $\mathrm{mAb}$ in allergic sheep was effective at preventing pulmonary late phase reactions (Abraham et al. 1994). Anti- $\alpha 4 \mathrm{mAb}$ was effective when given intravenously, before or after airway antigen challenge, and notably was effective when given by aerosol within the airways (Abraham et al. 1994). Despite its efficacy in blocking airway late phase reactions and bronchial hyperreactivity, this anti$\alpha 4 \mathrm{mAb}$ did not block influx of eosinophils into the lung. The efficacy of the anti- $\alpha 4 \mathrm{mAb}$ administered directly within the airways suggests that $\alpha 4$ integrin-mediated events with the airway lumen or adjacent tissues were involved in activation of responses of $\alpha 4$ bearing eosinophils and/or lymphocytes within the airways.

Other lymphocyte-mediated actions on eosinophils - Our studies have identified mechanisms by which eosinophils are capable of responding to lymphocyte-derived cytokines that do not enhance eosinophil effector functions. Eosinophils express CD4 (Lucey et al. 1989a) and migrate in response to the CD4-binding lymphokine, IL-16 (Rand et al. 1991a). Eosinophils express high affinity IL-2 receptors and migrate in response to IL-2 (Rand et al. 1991b). Eosinophils also express functional IL4 receptors, and IL-4 can enhance eosinophil HLADR expression (Weller et al. 1993). None of these cytokines directly promotes "traditional" eosinophil effector responses (e.g., degranulation); but their activities on eosinophils further indicate that eosinophils have non-"traditional" functions that can be modulated by lymphocyte-derived cytokines.

Potential specific roles for eosinophils as APCs - Diverse cells may function as APCs, but different APCs have distinct roles in presenting antigen as required for various immune responses, including initiating primary immune responses, expanding "memory" $\mathrm{T}$ cell populations, and potentially facilitating specific Th2 subset stimulation. These various immune responses occur in different tissue sites, including spleen and lymph nodes, and involve varied APCs, including dendritic cells, B cells and macrophages, that have different functional capabilities and roles. Specific roles for eosinophils as distinct APCs may be based on their capacities to handle particulate antigens, their anatomic localizations and subsequent tissue migrations, and their specific FcR-mediated abilities to internalize antigens.

- Particulate antigen processing: antigen processing involves the catabolism of antigens within APCs to produce immunogenic peptides that bind to Class II MHC molecules. The requisite initial internalization of antigens by APCs may occur via several mechanisms, including receptor-mediated antigen uptake (e.g. mediated by surface immunoglobulin on B cells), internalization of immune complexes by FcRs, nonspecific fluid phase or absorptive uptake, and phagocytosis. While dendritic cells and B cells very effectively present soluble protein antigens, they are unable to handle particulate antigens (van Rooijen 1990). In the respiratory tract, inhaled allergens are particulate 
(Platt-Mills 1992). Thus, while dendritic cells are known to migrate from the airways (Havenith et al. 1993, Xia et al. 1995), they would be ill-suited to process inhaled particulate aeroallergens. Although dendritic cells in subepithelial tissues may be effective APCs, it is unknown how particulate aeroallergens become solubilized and traverse from the epithelium to these dendritic cells. The principal cells recognized to ingest particulate antigens are phagocytic macrophages (van Rooijen 1992); but alveolar macrophages are not effective APCs and even antagonize APC function of dendritic cells (Gant et al. 1992, Holt et al. 1993, Chelen et al. 1995, MacLean et al. 1996). Alternatively, eosinophils would be well suited to handle particulate antigens, since eosinophils are phagocytic, characteristically engage large, even non-phagocytosable multicellular targets and accumulate early at tissue sites of particulate antigens (Kayes \& Oaks 1978, Weller 1991).

- Eosinophil tissue localization and migration: the normal localization of eosinophils within mucosal tissues of the respiratory, GI and lower GU tracts would position them to encounter foreign antigens at these mucosal surfaces. Moreover, in allergic airway diseases eosinophils are characteristically found directly within the lumen and secretions of airways. As noted above, these eosinophils express Class II MHC proteins (Hansel et al. 1991) and could directly interact with inhaled particulate allergens within the airways (Platt-Mills 1992).

- Antibody-mediated uptake of antigen: one especially effective means of facilitating antigen uptake and processing by APCs involves antibody targeting so that antigen is internalized complexed with antibody. Both IgG- and IgE-dependent enhancement of APC antigen presentation have been demonstrated. Antigen covalently coupled to antiFcyRI, RII or RIII receptor mAbs all enhanced antigen presentation by human monocyte/macrophages (Gosselin et al. 1992), and high affinity FceRIs on monocytes likewise have been shown to enhance allergen presentation (Maurer et al. 1995). Complexing specific IgE antibody with antigen (Der $p$ II) facilitated CD23-dependent antigen presentation by EBV-B cells, lowering 1000-fold the effective dose of antigen (van der Heijden et al. 1993). A role for IgE-mediated APC function in eliciting experimental allergic airway eosinophilia and Th2 cytokine expression has been indicated in anti-IgE treated and CD23 deficient mice (Coyle et al. 1996).

Human eosinophils express receptors for $\operatorname{IgG}$ (Hartnell et al. 1992), IgE (Capron et al. 1992) and IgA (Abu-Ghazaleh et al. 1989, Monteiro et al. 1993). Human eosinophil IgE receptors include a variant of CD23 (Grangette et al. 1989), the low affinity $\operatorname{IgE}$ receptor, and on some eosinophils, especially those from patients with allergic diseases, the high affinity FcERI receptor (Gounni et al. 1994b). Both CD23 and FceRI are detectable on eosinophils in sites of allergic reactions (Tanaka et al. 1995, Humbert et al. 1996), including the airways (Chihara et al. 1989, Humbert et al. 1996). In mucosal sites, eosinophils will be present with antibodies of all three classes; and for inhaled allergens, $\operatorname{IgG}, \operatorname{IgE}$ and $\operatorname{IgA}$ antibodies to relevant antigens are measurable in mucosal secretions (Platts-Mills 1979, Kitani et al. 1985, Desvaux et al. 1989). Interestingly, older studies of eosinophils had demonstrated that eosinophils were very effective in the uptake of antigen-antibody complexes (Sabesin 1963, Litt 1964a).

Thus, specific roles for the eosinophil as an APC may be related to its capacity to process inhaled particulate allergens, its localization at and migration from mucosal surfaces, and its expression of $F c \varepsilon, F c \alpha$ and $F c \gamma$ receptors in sites where antibodies of these classes are directed against relevant antigens. Thus, the hypothesis relevant to allergic asthma, in which inhaled allergens, e.g. mite or cockroach, repetitively enter the airways, is that Class II MHC expressing eosinophils, characteristically present within the airways, have roles in processing antigen, transporting it into tissues and presenting it to lymphocytes. Allergen-specific IgE and eosinophil FceRs would facilitate this APC function of eosinophils. Eosinophils as APCs may even bias lymphocyte responses to enhance Th2 responses (Wyss-Coray et al. 1993). This process of continued antigen-presentation helps account for the chronicity of allergic inflammation in response to inhaled allergens.

\section{REFERENCES}

Abraham WM, Sielczak MW, Ahmed A, Cortes A, Lauredo IT, Kim J, Pepinsky B, Benjamin CD, Leone DR, Lobb RR, Weller PF 1994. Anti- $\alpha 4$ intergrin mediates antigen-induced late bronchial responses and prolonged airway hyperresponsiveness in sheep. J Clin Invest 93: 776-787.

Abu-Ghazaleh RI, Fujisawa T, Mestecky J, Kyle RA, Gleich GJ 1989. IgA-induced eosinophil degranulation. J Immunol 142: 2393-2400.

Ahuja SS, Paliogianni F, Yamada H, Balow JE, Boumpas DT 1993. Effect of transforming growth factor- $\beta$ on early and late activation events in human T cells. $J$ Immunol 150: 3109-3118.

Aiello FB, Longo DL, Overton R, Takacs L, Durum SK 1990. A role for cytokines in antigen presentation: IL-1 and IL-4 induce accessory functions of antigen-presenting cells. J Immunol 144: 2572-2581.

Beil WJ, Weller PF, Tzizik DM, Galli SJ, Dvorak AM 1993. Ultrastructural immunogold localization of tumor necrosis factor to the matrix compartment of human eosinophil secondary granules. J Histochem 
Cytochem 41: 1611-1615.

Beninati W, Derdak S, Dixon PF, Grider DJ, Strollo DC, Hensley RE, Lucey DR 1993. Pulmonary eosinophils express HLA-DR in chronic eosinophilic pneumonia. J Allergy Clin Immunol 92: 442-449.

Bentley AM, Meng Q, Robinson DS, Hamid Q, Kay AB, Durham SR 1993. Increases in activated T lymphocytes, eosinophils, and cytokine mRNA expression for interleukin-5 and granulocyte/macrophage colony-stimulating factor in bronchial biopsies after allergen challenge in atopic asthmatics. Am J Respir Cell Mol Biol 8: 35-42.

Berlin C, Berg EL, Briskin MJ, Andrew DP, Kilshaw PJ, Holzmann B, Weissman IL, Hamann A, Butcher EC 1993. $\alpha 4 \beta 7$ integrin mediates lymphocyte binding to the mucosal vascular addressin MAdCAM-1. Cell 74: 185.

Bochner BS, Luscinskas FW, Gimbrone MAJ, Newman W, Sterbinsky SA, Derse-Anthony CP, Klunk D, Schleimer RP 1991. Adhesion of human basophils, eosinophils, and neutrophils to interleukin 1-activated human vascular endothelial cells: contributions of endothelial cell adhesion molecules. J Exp Med 173: 1553-1557.

Bosse M, Audette M, Ferland C, Pelletier G, Chu HW, Dakhama A, Lavigne S, Boulet LP, Laviolette M 1996. Gene expression of interleukin-2 in purified human peripheral blood eosinophils. Immunology 87: 149-154.

Braun RK, Franchini M, Erard F, Rihs S, De Vries IJM, Blaser K, Hansel TT, Walker C 1993. Human peripheral blood eosinophils produce and release interleukin-8 on stimulation with calcium ionophore. Eur J Immunol 23: 956-960.

Broide DH, Paine MM, Firestein GS 1992. Eosinophils express interleukin 5 and granulocyte macrophagecolony- stimulating factor mRNA at sites of allergic inflammation in asthmatics. J Clin Invest 90: 14141424.

Butterworth AE 1984. Cell-mediated damage to helminths. Adv Parasitol 23: 143-235.

Capron M, Truong MJ, Aldebert D, Gruart V, Suemura M, Delespesse G, Tourvieille B, Capron A 1992. Eosinophil IgE receptor and CD23. Immunol Res 11: 252-259.

Cella M, Scheidegger D, Palmer-Lehmann K, Lane P, Lanzavecchia A, Alber G 1996. Ligation of CD40 on dendritic cells triggers production of high levels of interleukin-12 and enhances T cell stimulatory capacity: T- T help via APC activation. J Exp Med 184: 747-752.

Chelen CJ, Fang Y, Freeman GJ, Secrist H, Marshall JD, Hwang PT, Frankel LR, DeKruyff RH, Umetsu DT 1995. Human alveolar macrophages present antigen ineffectively due to defective expression of B7 costimulatory cell surface molecules. J Clin Invest 95: 1415-1421.

Chihara J, Kubo H, Sakurada R, Yamamoto J, Nakano N, Sugihara R, Nakajima S 1989. [IgE-Fc receptor expressions on bronchoalveolar lavage (BAL) cells in a patient with eosinophilic pneumonia accompanied with bronchial asthma-the effect of ketotifen on their expression]. Arerugi 38: 326-333.
Costa JJ, Matossian K, Beil WJ, Wong DTW, Gordon JR, Dvorak AM, Weller PF, Galli SJ 1993. Human eosinophils can express the cytokines TNF- $\alpha$ and MIP-1 $\alpha . J$ Clin Invest 91: 2673-2684.

Coyle AJ, Wagner K, Bertrand C, Tsuyuki S, Bews J, Heusser C 1996. Central role of immunoglobulin (Ig) $\mathrm{E}$ in the induction of lung eosinophil infiltration and $\mathrm{T}$ helper 2 cell cytokine production: inhibition by a non-anaphylactogenic anti-IgE antibody. J Exp Med 183: 1303-1310.

Cruikshank WW, Center DM, Nisar N, Wu M, Natke B, Theodore AC, Kornfeld H 1994. Molecular and functional analysis of a lymphocyte chemoattractant factor: association of biologic function with CD4 expression. Proc Natl Acad Sci USA 91: 5109-5113.

Cruikshank WW, Lim K, Theodore AC, Cook J, Fine G, Weller PF, Center DM 1996. IL-16 inhibition of CD3-dependent lymphocyte activation and proliferation. J Immunol 157: 5240-5248.

Czech W, Krutmann J, Budnik A, Schopf E, Kapp A 1993. Induction of intercellular adhesion molecule 1 (ICAM-1) expression in normal human eosinophils by inflammatory cytokines. J Invest Dermatol 100: 417-423.

Del Pozo V, De Andrés B, Martín E, Cárdaba B, Fernández JC, Gallardo S, Tramón P, Leyva-Cobian F, Palomino P, Lahoz C 1992. Eosinophil as antigen-presenting cell: activation of $\mathrm{T}$ cell clones and $\mathrm{T}$ cell hybridoma by eosinophils after antigen processing. Eur J Immunol 22: 1919-1925.

Desreumaux P, Janin A, Colombel JF, Prin L, Plumas J, Emiliee D, Torpier G, Capron A, Capron M 1992. Interleukin-5 messenger RNA expression by eosinophils in the intestinal mucosa of patients with coeliac disease. J Exp Med 175: 293-296.

Desvaux FX, Peltre G, David B 1989. Characterization of grass pollen-specific $\operatorname{IgE}, \operatorname{Ig} \mathrm{A}, \operatorname{IgM}$ classes and IgG subclasses in allergic patients. Int Arch Allergy Appl Immunol 89: 281-287.

Dobrina A, Menegazzi R, Carlos TM, Nardon E, Cramer, R, Zacchi T, Harlan JM, Patriarca P 1991. Mechanisms of eosinophil adherence to cultured vascular endothelial cells. Eosinophils bind to the cytokineinduced ligand vascular cell adhesion molecule-1 via the very late activation antigen-4 integrin receptor. J Clin Invest 88: 20-26.

Elices MJ, Osborn L, Takada Y, Crouse C, Luhowskyj S, Hemler ME, Lobb RR 1990. VCAM-1 on activated endothelium interacts with the leukocyte integrin VLA-4 at a site distinct from the VLA-4/ fibronectin binding site. Cell 60: 577-584.

Elovic A, Wong DTW, Weller PF, Matossian K, Galli SJ 1994. Expression of TGF- $\alpha$ and TGF- $\beta_{1}$ mRNA and product by eosinophils in nasal polyps. J Allergy Clin Immunol 93: 864-876.

Erle DJ, Briskin MJ, Butcher EC, Garcia-Pardo A, Lazorovits AI, Tidswell M 1994. Expression and function of the MAdCAM-1 receptor, integrin $\alpha 4 \beta 7$, on human leukocytes. J Immunol 153: 517-528.

Foster PS, Hogan SP, Ramsay AJ, Matthaei KI, Young IG 1996. Interleukin 5 deficiency abolishes eosinophilia, airways hyperreactivity, and lung damage in a mouse asthma model. J Exp Med 183: 195-201. 
Gant VA, Shakoor Z, Hamblin AS 1992. A new method for measuring clustering in suspension between accessory cells and T lymphocytes. J Immunol Methods 156: 179-189.

Gleich GJ, Adolphson CR, Leiferman KM 1992. Eosinophils, p. 663-700. In Inflammation: basic principles and clinical correlates. 2nd ed., New York, Raven Press.

Gosselin EJ, Wardwell K, Gosselin DR, Alter N, Fisher JL, Guyre PM 1992. Enhanced antigen presentation using human Fc gamma receptor (monocyte/macrophage)-specific immunogens. J Immunol 149: 3477-3481.

Gounni AS, Lamkhioued B, Delaporte E, Dubost A, Kinet JP, Capron A, Capron M 1994a. The highaffinity $\mathrm{IgE}$ receptor on eosinophils: from allergy to parasites or from parasites to allergy? J Allergy Clin Immunol 94: 1214-1216.

Gounni AS, Lamkhioued B, Ochiai K, Tanaka Y, Delaporte E, Capron A, Kinet JP, Capron M 1994b. High-affinity IgE receptor on eosinophils is involved in defence against parasites. Nature 367: 183-186.

Grangette C, Gruart V, Ouaissi MA, Rizvi F, Delespesse G, Capron A, Capron M 1989. IgE receptor on human eosinophils (FcERII). Comparison with B cell CD23 and association with an adhesion molecule. $J$ Immunol 143: 3580-3588.

Guida L, O’Hehir RE, Hawrylowicz CM 1994. Synergy between dexamethasone and interleukin-5 for the induction of major histocompatibility complex class II expression by human peripheral blood eosinophils. Blood 84: 2733-2740.

Hamid Q, Barkans J, Meng Q, Ying S, Abrams JS, Kay AB, Moqbel R 1992. Human eosinophils synthesize and secrete interleukin-6, in vitro. Blood 80: 14961501.

Hansel TT, Braunstein JB, Walker C, Blaser K, Bruijnzeel PLB, Virchow JC Jr, Virchow C 1991. Sputum eosinophils from asthmatics express ICAM1 and HLA-DR. Clin Exp Immunol 86: 271-277.

Hansel TT, De Vries IJM, Carballido JM, Braun RK, Carballido-Perrig N, Rihs S, Blaser K, Walker C 1992. Induction and function of eosinophil intercellular adhesion molecule-1 and HLA-DR. J Immunol 149: 2130-2136.

Harding CV, Unanue ER 1990. Quantitation of antigenpresenting cell MHC class II/peptide complexes necessary for T-cell stimulation. Nature 346: 574-576.

Hartnell A, Kay AB, Wardlaw AJ 1992. IFN-gamma induces expression of Fc gamma RIII (CD16) on human eosinophils. J Immunol 148: 1471-1478.

Havenith CE, van Miert PP, Breedijk AJ, Beelen RH, Hoefsmit EC 1993. Migration of dendritic cells into the draining lymph nodes of the lung after intratracheal instillation. Am J Respir Cell Mol Biol 9: 484488.

Herndon FJ, Kayes SG 1992. Depletion of eosinophils by anti-IL-5 monoclonal antibody treatment of mice infected with Trichinella spiralis does not alter parasite burden or immunologic resistance to reinfection. J Immunol 149: 3642-3647.

Holt PG, Oliver J, Bilyk N, McMenamin C, McMenamin
PG, Kraal G, Thepen T 1993. Downregulation of the antigen presenting cell function(s) of pulmonary dendritic cells in vivo by resident alveolar macrophages. J Exp Med 177: 397-407.

Humbert M, Grant JA, Taborda-Barata L, Durham SR, Pfister R, Menz G, Barkans J, Ying S, Kay AB 1996. High-affinity IgE receptor (FceRI)-bearing cells in bronchial biopsies from atopic and nonatopic asthma. Am J Resp Crit Care Med 153: 1931-1937.

Iwamoto I, Nakajima H, Endo H, Yoshida S 1993. Interferon gamma regulates antigen-induced eosinophil recruitment into the mouse airways by inhibiting the infiltration of CD4 ${ }^{+} \mathrm{T}$ cells. J Exp Med 177: 573-576.

Kayes SG, Oaks JA 1978. Development of the granulomatous response in murine toxocariasis. Initial events. Am J Pathol 93: 277-294.

Kita H, Ohnishi T, Okubo Y, Weiler D, Abrams JS, Gleich GJ 1991. Granulocyte/macrophage colonystimulating factor and interleukin 3 release from human peripheral blood eosinophils and neutrophils. J Exp Med 174: 745-748.

Kitani S, Ito K, Miyamoto T 1985. IgG, IgA, and IgM antibodies to mite in sera and sputa from asthmatic patients. Ann Allergy 55: 612-620.

Kraal G, Schornagel K, Streeter PR, Holzmann B, Butcher EC 1995. Expression of the mucosal vascular addressin, MAdCAM-1, on sinus- lining cells in the spleen. Am J Pathol 147: 763-771.

Lamkhioued B, Aldebert D, Gounni AS, Delaporte E, Goldman M, Capron A, Capron M 1995. Synthesis of cytokines by eosinophils and their regulation. Int Arch Allergy Immunol 107: 122-123.

Lee H-M, Rich S 1993. Differential activation of CD8 ${ }^{+}$ $\mathrm{T}$ cells by transforming growth factor- $\beta 1$. J Immunol 151: 668-677.

Levi-Schaffer F, Barkans J, Newman TM, Ying S, Wakelin M, Hohenstein R, Barak V, Lacy P, Kay AB, Moqbel R 1996. Identification of interleukin-2 in human peripheral blood eosinophils. Immunology 87: 155-161.

Lim K, Wan H-C, Resnick M, Wong DTW, Cruikshank WW, Kornfeld H, Center DM, Weller PF 1995. Human eosinophils release the lymphocyte and eosinophil active cytokines, RANTES and lymphocyte chemoattractant factor (LCF). Int Arch Allergy Immunol 107: 342.

Lim KG, Wan H-C, Bozza PT, Resnick MB, Wong DTW, Cruikshank DTW, Kornfeld H, Center DM, Weller PF 1996a. Human eosinophils elaborate the lymphocyte chemoattractants: IL-16 (lymphocyte chemoattractant factor, LCF) and RANTES. $J$ Immunol 156: 2522-2527.

Lim KG, Wan HC, Geha R, Weller PF 1996b. Accessory cell function of eosinophils: CD40-mediated T cell proliferation. Am J Respir Crit Care Med 153: A55.

Litt M 1963. Studies of experimental eosinophilia. V. Eosinophils in lymph nodes of guinea pigs following primary antigenic stimulation. Am J Pathol 42: 529-550.

Litt M 1964a. Studies in experimental eosinophilia VI. 
Uptake of immune complexes by eosinophils. J Cell Biol 23: 355-361.

Litt M 1964b. Studies in experimental eosinophilia VII. Eosinophils in lymph nodes during the first $24 \mathrm{hr}$ following primary antigenic stimulation. J Immunol 93: 807-813.

Lucey DR, Dorsky DI, Nicholson-Weller A, Weller PF 1989a. Human eosinophils express CD4 protein and bind HIV-1 GP120. J Exp Med 169: 327-332.

Lucey DR, Nicholson-Weller A, Weller PF 1989b. Mature human eosinophils have the capacity to express HLA-DR. Proc Natl Acad Sci USA 86: 1348-1351.

MacLean JA, Xia W, Pinto CE, Zhao L, Liu H-W, Kradin RL 1996. Sequestration of inhaled particulate antigens by lung phagocytes. A mechansism for the effective inhibition of pulmonary cell-mediated immunity. Am J Pathol 148: 657-666.

Maurer D, Ebner C, Reininger B, Fiebiger E, Kraft D, Kinet JP, Stingl G 1995. The high affinity IgE receptor (Fc epsilon RI) mediates IgE-dependent allergen presentation. J Immunol 154: 6285-6290.

Melani C, Mattia GF, Silvani A, Care A, Rivoltini L, Parmiani G, Colombo MP 1993. Interleukin-6 expression in human neutrophil and eosinophil peripheral blood granulocytes. Blood 81: 2744-2749.

Mengelers HJ, Maikoe T, Brinkman L, Hooibrink B, Lammers J-WJ, Koenderman L 1994. Immunophenotyping of eosinophils recovered from blood and BAL of allergic asthmatics. Am J Respir Crit Care Med 149: 345-351.

Mengelers HJ, Maikoe T, Raaijmakers JA, Lammers JW, Koenderman L 1995. Cognate interaction between human lymphocytes and eosinophils is mediated by beta 2-integrins and very late antigen-4. J Lab Clin Med 126: 261-268.

Minami Y, Kono T, Miyaki T, Taniguchi T 1993. The IL-2 receptor complex: its structure, function, and target genes. Annu Rev Immunol 11: 245-268.

Monteiro RC, Hostoffer RW, Cooper MD, Bonner JR, Gartland GL, Kubagawa H 1993. Definition of immunoglobulin A receptors on eosinophils and their enhanced expression in allergic individuals. J Clin Invest 92: 1681-1685.

Moqbel R, Hamid Q, Ying S, Barkans J, Hartnell A, Tsicopoulos A, Wardlaw AJ, Kay AB 1991. Expression of mRNA and immunoreactivity for the granulocyte/macrophage colony-stimulating factor in activated human eosinophils. J Exp Med 174: 749-752.

Moqbel R, Ying S, Barkans J, Newman TM, Kimmitt P, Wakelin M, Taborda-Barata L, Meng Q, Corrigan CJ, Durham SR, Kay AB 1995. Identification of mesenger RNA for IL-4 in human eosinophils with granule localization and release of the translated product. J Immunol 155: 4939-4947.

Muñoz M, Serrador J, Sánchez-Madrid F, Teixidó J 1996. A region of the integrin VLA $\alpha 4$ subunit involved in homotypic cell aggregation and in fibronectin but not vascular cell adhesion molecule-1 binding. J Biol Chem 271: 2696-2702.

Nonaka M, Nonaka R, Woolley K, Adelroth E, Miura K, Okhawara Y, Glibetic M, Nakano K, O'Byrne P, Dolovich J, Jordana M 1995. Distinct immunohis- tochemical localization of IL-4 in human inflamed airway tissues. IL-4 is localized to eosinophils in vivo and is released by peripheral blood eosinophils. J Immunol 155: 3234-3244.

Ohkawara Y, Lim KG, Xing Z, Glibetic M, Nakano K, Dolovich J, Croitoru K, Weller PF, Jordana M 1996. CD40 expression by human peripheral blood eosinophils. J Clin Invest 97: 1761-1766.

Ohkawara Y, Yamauchi K, Maruyama N, Hoshi H, Ohno I, Honma M, Tanno Y, Tamura G, Shirato K, Ohtani H 1995. In situ expression of the cell adhesion molecules in bronchial tissues from asthmatics with air flow limitation: in vivo evidence of VCAM-1/VLA4 interaction in selective eosinophil infiltration. Am J Respir Cell Mol Biol 12: 4-12.

Ohnishi T, Kita H, Weiler D, Sur S, Sedgwick JB, Calhoun WJ, Busse WW, Abrams JS, Gleich GJ 1993. IL-5 is the predominant eosinophil-active cytokine in the antigen-induced pulmonary latephase reaction. Am Rev Resp Dis 147: 901-907.

Ohno I, Lea R, Finotto S, Marshall J, Denburg J, Dolovich J, Gauldie J, Jordana M 1991. Granulocyte/macrophage colony-stimulating factor (GM$\mathrm{CSF}$ ) gene expression by eosinophils in nasal polyposis. Am J Respir Cell Mol Biol 5: 505-510.

Ohno I, Lea RG, Flanders KC, Clark DA, Banwatt D, Dolovich J, Denburg J, Harley CB, Gauldie J, Jordana M 1992. Eosinophils in chronically inflamed human upper airway tissues express transforming growth factor beta 1 gene (TGF beta 1). J Clin Invest 89: 1662-1668.

Okubo Y, Hossain M, Kai R, Sato E, Honda T, Sekiguchi, M, Itoh S, Takatsu K 1995. Adhesion molecules on eosinophils in acute eosinophilic pneumonia. Am J Respir Crit Care Med 151: 1259-1262.

Peng X, Kasran A, Warmerdam PA, de Boer M, Ceuppens JL 1996. Accessory signaling by CD40 for $\mathrm{T}$ cell activation: induction of Th1 and Th2 cytokines and synergy with interleukin-12 for interferon-gamma production. Eur J Immunol 26: 16211627.

Platt-Mills TAE 1992. Mechanisms of bronchial reactivity: the role of immunoglobulin E. Am Rev Resp Dis 145: S44-S7.

Platts-Mills TA 1979. Local production of IgG, IgA and IgE antibodies in grass pollen hay fever. J Immunol 122: 2218-2225.

Pretolani M, Ruffie C, Lapa e Silva JR, Joseph D, Lobb RR, Vargaftig BB 1994. Antibody to very late activation antigen 4 prevents antigen-induced bronchial hyperreactivity and cellular infiltration in the guinea pig airways. J Exp Med 180: 795-805.

Rand TH, Cruikshank WW, Center DM, Weller PF 1991a. CD4-mediated stimulation of human eosinophils: Lymphocyte chemoattractant factor and other CD4-binding ligands elicit eosinophil migration. J Exp Med 173: 1521-1528.

Rand TH, Silberstein DS, Kornfeld H, Weller PF 1991b. Human eosinophils express functional interleukin 2 receptors. J Clin Invest 88: 825-832.

Resnick MB, Weller PF 1993. Mechanisms of eosinophil recruitment. Am J Resp Cell Mol Biol 8: 349-355. 
Roberts AN 1966. Cellular localization and quantitation of tritiated antigen in mouse lymph nodes during early primary immune response. Am J Pathol 49: 889-909.

Rott LS, Briskin MJ, Andrew DP, Berg EL, Butcher EC 1996. A fundamental subdivision of circulating lymphocytes defined by adhesion to mucosal cell adhesion molecule-1. J Immunol 156: 3727-3736.

Ruppert J, Peters JH 1991. IL-6 and IL-1 enhance the accessory activity of human blood monocytes during differentiation to macrophages. J Immunol 146: 144-149.

Sabesin SM 1963. A function of the eosinophil: phagocytosis of antigen-antibody complexes. Proc Soc Exp Biol Med 112: 667-671.

Sabin EA, Kopf MA, Pearce EJ 1996. Schistosoma mansoni egg-induced early IL-4 production is dependent upon IL-5 and eosinophils. J Exp Med 184: 1871-1878.

Sakamoto S, Oki K, Takahashi H, Arakawa Y, Sugita H, Kawabata Y, Takeuchi K, Tomichi N 1995a. Surface antigens on eosinophils in bronchial asthma and eosinophilic pneumonia. Int Arch Allergy Immunol 108 (Suppl 1): 6-8.

Sakamoto S, Oki K, Takahashi Y, Arakawa Y, Kawata Y, Takeuchi K, Tomichi N 1995b. Surface antigens of eosinophils in peripheral blood and BALF of patients with eosinophilic pneumonia. Am Rev Resp Crit Care Med 151: A219.

Schall TJ, Bacon K, Toy KJ, Goeddel DV 1990. Selective attraction of monocytes and T lymphocytes of the memory phenotype by cytokine RANTES. $\mathrm{Na}$ ture 347: 669-671.

Schweighoffer T, Tanaka Y, Tidswell M, Erle DJ, Horgan KJ, Ginther Luce GE, Lazarovits AI, Buck D, Shaw S 1993. Selective expression of integrin $\alpha 4 \beta 7$ on a subset of human $\mathrm{CD}^{+}$memory $\mathrm{T}$ cells with hallmarks of gut-trophism. J Immunol 151: 717-729.

Sedgwick JB, Calhoun WJ, Vrtis RF, Bates ME, McAllister PK, Busse WW 1992. Comparison of airway and blood eosinophil function after in vivo antigen challenge. J Immunol 149: 3710-3718.

Sedgwick JB, Quan SF, Calhoun WJ, Busse WW 1995. Effect of interleukin-5 and granulocyte-macrophage colony stimulating factor on in vitro eosinophil function: comparison with airway eosinophils. J Allergy Clin Immunol 96: 375-385.

Sher A, Coffman RL, Hieny S, Cheever AW 1990. Ablation of eosinophil and IgE responses with anti-IL5 or anti-IL-4 antibodies fails to affect immunity against Schistosoma mansoni in the mouse. $J$ Immunol 145: 3911-3916.

Tamura N, Ishii N, Nakazawa M, Nagoya M, Yoshinari M, Amano T, Nakazima H, Minami M 1996. Requirement of CD80 and CD86 molecules for antigen presentation by eosinophils. Scand J Immunol 44: 229-238.

Tanaka Y, Takenaka M, Matsunaga Y, Okada S, Anan S, Yoshida H, Ra C 1995. High affinity IgE receptor (Fc epsilon RI) expression on eosinophils infiltrating the lesions and mite patch tested sites in atopic dermatitis. Arch Dermatol Res 287: 712-717.
Taub DD, Conlon K, Lloyd AR, Oppenheim JJ, Kelvin DJ 1993. Preferential migration of activated CD4 ${ }^{+}$ and $\mathrm{CD}^{+} \mathrm{T}$ cells in response to MIP- $1 \alpha$ and MIP-

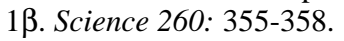

Taub DD, Ortaldo JR, Turcovski-Corrales SM, Key ML, Longo DL, Murphy WJ 1996. Beta chemokines costimulate lymphocyte cytolysis, proliferation, and lymphokine production. J Leukoc Biol 59: 81-89.

Urban JF, Madden KB, Svetic A, Cheever A, Trotta PP, Gausse WC, Katona IM, Finkelman FD 1992. The importance of Th2 cytokines in protective immunity to nematodes. Immunol Rev 127: 205-220.

van der Heijden FL, Joost van Neerven RJ, van Katwijk M, Bos JD, Kapsenberg ML 1993. Serum-IgE-facilitated allergen presentation in atopic disease. $J$ Immunol 150: 3643-3650.

Van Oosterhout AJ, Ladenius AR, Savelkoul HF, Van Ark I, Delsman KC, Nijkamp FP 1993. Effect of anti-IL-5 and IL-5 on airway hyperreactivity and eosinophils in guinea pigs. Am Rev Respir Dis 147: 548-552.

van Rooijen N 1990. Antigen processing and presentation in vivo: the microenvironment as a crucial factor. Immunol Today 11: 436-439.

van Rooijen N 1992. Macrophages as accessory cells in the in vivo humoral immune response: from processing of particulate antigens to regulation by suppression. Semin Immunol 4: 237-245.

Wan H-C, Lazarovits AI, Cruikshank WW, Kornfeld H, Center DM, Weller PF 1995. Expression of $\alpha 4 \beta 7$ integrin on eosinophils and modulation of $\alpha 4$ integrin-mediated eosinophil adhesion via CD4. Int Arch Allergy Immunol 107: 343-344.

Wardlaw AJ, Kay AB 1992. Interrelationship between T lymphocytes and eosinophils, p. 261-271. In Eosinophils: biological and clinical aspects. Boca Raton, CRC Press.

Weg VB, Williams TJ, Lobb RR, Nourshargh S 1993. A monoclonal antibody recognizing very late activation antigen-4 inhibits eosinophil accumulation in vivo. J Exp Med 177: 561-566.

Weller PF 1991. The immunobiology of eosinophils. New Engl J Med 324: 1110-1118.

Weller PF 1993. Lipid, peptide and cytokine mediators elaborated by eosinophils, p. 25-42. In Immunopharmacology of eosinophils. The Handbook of immunopharmacology. London, Academic Press.

Weller PF, Rand TH, Barrett T, Elovic A, Wong DT, Finberg RW 1993. Accessory cell function of human eosinophils: HLA-DR dependent, MHC-restricted antigen-presentation and interleukin- $1 \alpha$ formation. J Immunol 150: 2554-2562.

Weller PF, Rand TH, Goelz SE, Chi-Rosso G, Lobb RJ 1991. Human eosinophil adherence to vascular endothelium mediated by binding to VCAM-1 and ELAM-1. Proc Natl Acad Sci USA 88: 7430-7433.

Wong DTW, Elovic A, Matossian K, Nagura N, McBride J, Gordon JR, Rand TH, Galli SJ, Weller PF 1991. Eosinophils from patients with blood eosinophilia express transforming growth factor $\beta_{1}$. Blood 78 : 2702-2707. 
Wong DTW, Weller PF, Galli SJ, Rand TH, Elovic A, Chiang T, Chou MY, Gallagher GT, Matossian K, McBride J, Todd R 1990. Human eosinophils express transforming growth factor $\alpha . J$ Exp Med 172: 673-681.

Wyss-Coray T, Gallati H, Pracht I, Limat A, Mauri D, Frutig K, Pichler WJ 1993. Antigen-presenting human T cells and antigen-presenting B cells induce a similar cytokine profile in specific T cell clones. Eur J Immunol 23: 3350-3357.
Xia W, Pinto CE, Kradin RL 1995. The antigen-presenting activities of Ia+ dendritic cells shift dynamically from lung to lymph node after an airway challenge with soluble antigen. $J$ Exp Med 181: 1275-1283.

Ying S, Meng Q, Taborda-Barata L, Corrigan CJ, Barkans J, Assoufi B, Moqbel R, Durham SR, Kay AB 1996. Human eosinophils express messenger RNA encoding RANTES and store and release biologically active RANTES protein. Eur J Immunol 26: $70-76$. 